\title{
Changes of the Erythrocyte Glucose-6-phosphate Dehydrogenase
}

\section{Activity during Treatment for Hyperthyroidism}

\section{Toshihiko MIHARA, Shôshi SHIMOYAMA, Sekiji MORITA, Isao MATSUOKA, Kiichi MATSUURA, Kyôju ABE and Yukimasa HIRATA}

The 1st Department of Internal Medicine, Tottori University School of Medicine, Yonago, Japan

It has been confirmed by many reporters that the erythrocyte glucose-6-phosphate dehydrogenase (G-6-PD) activity increased in the patients with hyperthyroidism. There have been a few reports dealing with the changes of erythrocyte G-6-PD activity during treatment for hyperthyroidism. However, the number of cases in these reports seems not enough to discuss the effects of the therapy for hyperthyroidism on G-6-PD activity. The aim of the present study is to investigate the relationship between the erythrocyte G-6PD activity and the effects of the treatment for hyperthyroidism in many cases.

Before and during treatment in 14 patients with hyperthyroidism the erythrocyte G-6-PD activity, resin sponge uptake of ${ }^{131} \mathrm{I}_{-} \mathrm{T}_{3}$ (Triosorb test) and protein-bound iodine (PBI) were determined simultaneously. G-6-PD activity was measured by the method of Kornberg-Horecker and it was represented as $\Delta \mathrm{OD} / \mathrm{min} . / \mathrm{gHb}$.

During the treatment of the patients with hyperthyroidism, the G-6-PD activity decreased significantly $(\mathrm{p}<0.05) \quad 3-4$ months after the treatment began and in 6 of 14 cases it became within normal range. In most patients with hyperthyroidism a normalization of elevated erythrocyte G-6-PD activity was slower than those of Triosorb and PBI values by the treatment. The decreasing rate of the erythrocyte G-6-PD activity during treatment for hyperthyroidism might differ from each other in the different method of treatment. It seemed that the cases treated previously by radioactive iodine showed a more rapid decrease of the erythrocyte G-6-PD activity with the second treatment by antithyroid drug than those who had never been treated by radioactive iodine.

(See pp. 691 697) 


\section{甲状腺機能立進症における赤血球 G-6-PD 活性 \\ —とくに治療の影響について}

\begin{tabular}{|c|c|c|c|c|c|}
\hline 三 & 原 & 俊 & 彦，下 & 山 & 晶 \\
\hline 森 & 田 & 積 & 二，松 & 周 & \\
\hline 安 & 部 & 喬 & 樹，松 & 浦 & 驥 \\
\hline 平 & 田 & 幸 & 正 & & \\
\hline
\end{tabular}

（昭和 47 年 11 月 28 日受付）

甲状腺機能六進症14例の治療による赤血球 G-6-PD 活性の推移を, Triosorb 值, PBI の推移ととも にみた，治療前における赤血球 G-6-PD 活性は，健常者に比し有意に高く，治療後は明らかに減少す るととを認めた，治療による赤血球 G-6-PD 活性の減少は，大部分の症例において Triosorb 値, PBI の減少におくれる傾向があったが，一部の例，特に以前放射性ヨードで治療しており，さらに抗甲状腺 剤で再治療した例では，赤血球 G-6-PD 活性も Triosorb 值 PBI とほぼ同時に正常化する傾向を認め た。

緒 言

甲状腺機能九進症において赤血球ブドウ糖 6 リン酸脱水素酵素（以下 G-6-PD と略す）活性が高いとい

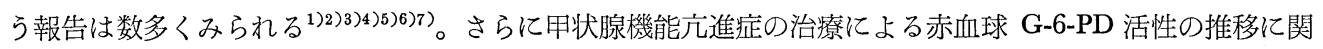
しては, 治療により赤血球 G-6-PD 活性か泟常化するという報告もみられるが22334)7)，その多くは数例の経 験にとどまつているようである．今回私共は甲状腺機能六進症治療による赤血球 G-6-PD 活性の推移につ いてあきらかにするため，14例の甲状腺機能九進症について治療の経過中数回にわたつて赤血球 G-6-PD 活性を Triosorb 值, PBI とともに測定した。 その結果, 治療方法ならびに治療効果と赤血球 G-6-PD 活 性との間に一定の密接な関係の存在するてとを認めることができた。

\section{研究対象および実験方法}

\section{1. 研究対象}

当内科に昭和 45 年11月より昭和46年 9 月までの期間中に治療を目的として入院した14名（男：2 名，女： 12名）の甲状腺機能進症患者を対象とした，そのうち4名は入院するまで全く治蹽を行つていないもので， 10名は入院までに何らかの治療を行っていたものである．その治潦内容は Table 1 に示す通りである．た だし，入院前はいずれも治療を中断しており，その治療中断期間は 2 週間から 12 力で平均 4 力月であつた. なお，高度の貧血のあるものは貧血の影響が G-6-PD 活性に現われるので対象から除外してある. 甲状腺 機能充進症治療による赤血球 G-6-PD 活性の変化は 1 ～12 力月平均 5 カ月にわたつて観察した。健常群と しては, 当内科勤務者で特別の疾患を有しない10名（男：7名，女：3名）をえらんだ。

\section{2. 実験方法}

赤血球 G-6-PD 活性の測定は Kornberg-Horecker の方法 ${ }^{87}$ 亿準じて行い，早朝空腹時に肘静脈よりへパリ ンを用いて $3 \mathrm{ml}$ 採血し, 直ちに 2,500 rpm にて冷却遠沈後上清および buffy layer を除去し, 冷却した生 
Table 1. Clinical data of the patients with hyperthyroidism on admission. M.....male. F......female. Meth.......Methimazole. PTU......Propylthiouracil.

\begin{tabular}{|c|c|c|c|c|c|c|c|c|}
\hline Case & Sex & Age & $\begin{array}{c}\text { Triosorb } \\
\%\end{array}$ & $\begin{array}{c}\text { PBI } \\
\mu \mathrm{g} / \mathrm{dl}\end{array}$ & $\begin{array}{c}\text { G-6-PD } \\
\Delta \mathrm{OD} / \mathrm{min} . / \mathrm{gHb}\end{array}$ & $\begin{array}{l}\text { Previous } \\
\text { therapy }\end{array}$ & $\begin{array}{l}\text { Period of non- } \\
\text { treatment closed } \\
\text { before present } \\
\text { therapy }\end{array}$ & $\begin{array}{l}\text { Methods of } \\
\text { present } \\
\text { therapy }\end{array}$ \\
\hline 1 & $\mathrm{~F}$ & 64 & 60 & 13.2 & 10.2 & ......... & .......... & Meth. \\
\hline 2 & $\mathrm{~F}$ & 43 & 63 & 21.6 & 11.3 & ......... & .......... & ${ }^{131} \mathrm{I}$, Meth. \\
\hline 3 & F & 41 & 47 & 15.5 & 11.4 & ......... & ......... & ${ }^{131} \mathrm{I}$, Meth. \\
\hline 4 & $\mathbf{M}$ & 36 & 51 & 19.4 & 10.3 & .......... & ......... & ${ }^{131} \mathrm{I}, \mathrm{PTU}$ \\
\hline 5 & F & 17 & 55 & 15.7 & 11.8 & Meth., PTU & 1 Month & PTU \\
\hline 6 & F & 29 & 49 & 12.8 & 8.92 & Meth. & 1.5 Months & Meth. \\
\hline 7 & F & 40 & 41 & 10.8 & 9.14 & Meth., PTU & 6 Months & ${ }^{131} \mathbf{I}$ \\
\hline 8 & $\mathrm{~F}$ & 29 & 49 & 12.7 & 13.4 & PTU, Meth. & 6 Months & ${ }^{131} \mathrm{I}, \mathrm{PTU}$ \\
\hline 9 & $\mathrm{~F}$ & 41 & 53 & 16.6 & 10.5 & Meth. & 1 Month & ${ }^{131} \mathrm{I}$, Meth. \\
\hline 10 & $\mathrm{~F}$ & 48 & 29 & 12.0 & 8.83 & Meth. & 3 Months & ${ }^{131} I$ \\
\hline 11 & $\mathbf{M}$ & 35 & 50 & 16.0 & 8.95 & ${ }^{131} \mathbf{I}$ (2 mal) & 1 Month & Meth. \\
\hline 12 & $\mathrm{~F}$ & 47 & 48 & 8.6 & 9.20 & ${ }^{131} \mathbf{I}$ & 6 Months & Meth. \\
\hline 13 & $\mathrm{~F}$ & 45 & 41 & 20.2 & 13.2 & ${ }^{131} \mathbf{I}$ & 12 Months & Meth. \\
\hline 14 & $\mathrm{~F}$ & 58 & 45 & 11.8 & 9.20 & ${ }^{131} \mathbf{I}$ & 2 Weeks & Meth. \\
\hline
\end{tabular}

理的食塩水にて 3 回洗涤後赤血球を50倍の脱イオン水に溶血させ, さらに $3,500 \mathrm{rpm}$ で泠却遠沈しその上清 を測定に供した。 反応液は 0.02M glucose-6-phosphate Na 塩 (Sigma) $0.15 \mathrm{ml}, 1.5 \times 10^{-3} \mathrm{M}$ NADP (Sigma) $0.1 \mathrm{ml}, 0.3 \mathrm{M} \mathrm{MgCl}_{2} 0.15 \mathrm{ml}$, Tris- $\mathrm{HCl}$ 緩衝液 $(\mathrm{pH} 7.6) 1.5 \mathrm{ml}$, 脱イオン水 $1.5 \mathrm{ml}$, さらに試料の溶血液

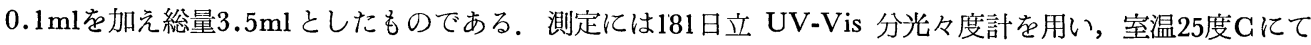
反応液混和後 5 分より15分まで 1 分でとに波長 $340 \mathrm{~m} \mu$ にて NADP から $\mathrm{NADPH}_{2}$ への還元による吸光 度の増加をよみとり， G-6-PD 活性は，単位へモグロビンあたりの 1 分間の平均吸光度の増加 $\Delta \mathrm{OD} / \mathrm{min}$./ $\mathrm{gHb}$ であらわした，溶血液のへモグロビン濃度は，溶血液 $0.1 \mathrm{ml}$ を用い，へモキットN（日本商事 $\mathrm{KK}$ ） を用いてシアンメトヘモグロビン法で測定した．Triosorb 值はダイナボットRI 研究所製キットにて測定 し (正常範囲25-38\%), PBI は Barker のアルカリ灰化法でテクニコンオートアナライザーにて測定した (正常範囲 $4.0 \sim 8.0 \mu \mathrm{g} / \mathrm{dl}$ )。

\section{実 験 成 績}

\section{1. 甲状腺機能穴進症の治療前後における赤血球 G-6-PD 活性の推移.}

甲状腺機能元進症の治療開始後 1 2 力月, $3 \sim 4$ 力月, $5 \sim 7$ 力月, 12力月の時点における赤血球 G6-PD 活性の推移をみると，Fig. 1 亿示すように，1２力月の時点においては治療前に比して，むしろ活 性が上昇する例もみられるが，治療開始後 3〜 4 カ月，5〜 7 カ月と治療期間が長くなるにつれて，1 例を 除き赤血球 G-6-PD 活性は減少する傾向にあり，14例中 6 例において正常化している. 治療開始後 $1 \sim 2$ カ月, $3 \sim 4$ カ月, $5 \sim 7$ カ月の各時点で, 赤血球 G-6-PD 活性を測定し得た症例の赤血球 G-6-PD 活性 および同時に測定した Triosorb 值 PBI の平均值の推移をみると，Table 2 亿示すように1〜2 カ月の時 点では, Triosorb 值は正常となつているが, PBI はやや高めであり, 赤血球 G-6-PD 活性も治療前值と大 差がない. 治療開始後 $3 \sim 4$ カ月, $5 \sim 7$ カ月の時点では, Triosorb 值, PBI ともに正常となり, 赤血球 G-6-PD 活性も同じ症例の治療前值に比し，推計学的に有意に減少 $(\mathrm{p}<0.05)$ している. しかし平均值の うえではまだ正常となつていず，赤血球 G-6-PD 活性は Triosorb 值 PBI よりおくれて正常化する傾向が うかがえる. 5〜 7 カ月の時点の赤血球 G-6-PD 活性が， 3〜4 カ月の時点のものより高いのは, 各時期 
Fig. 1. The erythrocyte G-6-PD activity before and after the treatment of the patients with hyperthyroidism. The shaded areas represents normal range.

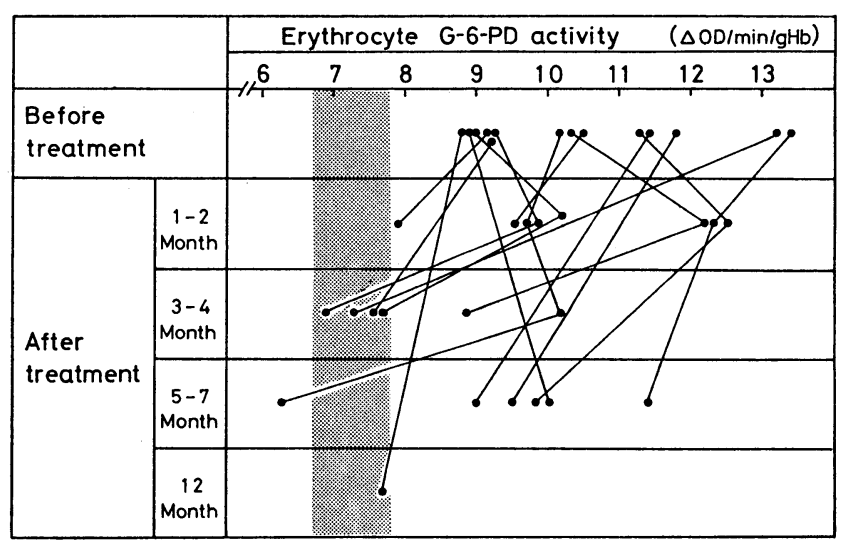

Table 2. The erythrocyte G-6-PD activity, Triosorb and PBI before and after the treatment of the patients with hyperthyroidism. Results expressed as mean \pm S.E.M.

Values in parentheses indicate normal range.

\begin{tabular}{|c|c|c|c|c|c|}
\hline & & \multirow{2}{*}{$\begin{array}{c}\text { case } \\
\text { number }\end{array}$} & $\begin{array}{l}\text { G-6-PD activity } \\
\text { in the erythrocyte }\end{array}$ & Triosorb & PBI \\
\hline & & & $\underset{(6.7-7.8)}{\Delta \mathrm{OD} / \mathrm{min} . / \mathrm{gHb}}$ & $\begin{array}{c}\% \\
(25-38)\end{array}$ & $\begin{array}{l}\mu \mathrm{g} / \mathrm{dl} \\
(4.0-8.0)\end{array}$ \\
\hline \multicolumn{2}{|c|}{ Before treatment } & 12 & $10.45 \pm 0.42$ & $49 \pm 2.3$ & $14.8 \pm 1.0$ \\
\hline \multirow{3}{*}{$\begin{array}{c}\text { After } \\
\text { treatment }\end{array}$} & $\begin{array}{c}1-2 \\
\text { Month }\end{array}$ & 8 & $\begin{array}{c}\{10.37 \pm 0.52\} \\
10.50 \pm 0.58^{*}\end{array}$ & $34 \pm 2.6$ & $10.1 \pm 1.6$ \\
\hline & $\begin{array}{c}3-4 \\
\text { Month }\end{array}$ & 6 & $\begin{array}{r}{[10.18 \pm 0.65]} \\
8.07 \pm 0.51^{* *}\end{array}$ & $31 \pm 1.4$ & $5.6 \pm 1.3$ \\
\hline & $\begin{array}{c}5-7 \\
\text { Month }\end{array}$ & 6 & $\begin{array}{l}〔 11.17 \pm 0.62 〕 \\
633 \pm 0.69^{* *}\end{array}$ & $32 \pm 2.6$ & $6.7 \pm 0.7$ \\
\hline
\end{tabular}

* There is no significant difference between the initial values $〔 〕$ and after treatment in the same patients.

** There is a significant difference $(\mathrm{p}<0.05)$ between the initial values 〔 $]$ and after treatment in the same patients.

に測定し得た症例の差によるものである。

2. 甲状腺機能六進症の治療法別にみた赤血球 G-6-PD 活性の推移.

1 ) 抗甲状腺剤単独治療例 (Fig. 2)

Table 1 における Case 1 の症例であるが, Triosorb 值, PBI は治療開始後 1 力月で正常化しているが, 赤血球 G-6-PD 活性の低下はかなりおくれて 6 カ月後の測定において正常值を示した.

2 ) 放射性ヨード，抗甲状腺剤併用例 (Fig. 3)

Table 1 における Gase 2, Case 3, Gase 4 であるが, 全例ておいて Triosorb 值は 2 カ月後, PBI は 3 
Fig. 2. Changes of the erythrocyte G-6-PD activity, Triosorb and PBI in the patient with hyperthyroidism treated by methimazole. Gase 1 in Table $1 . \quad$ The shaded areas represents normal ranges.

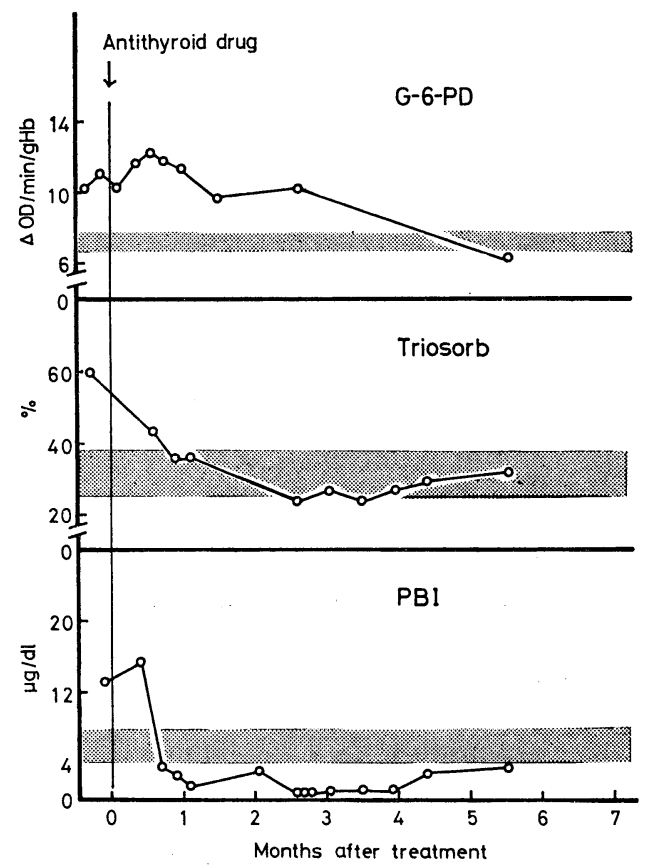

カ月後に正常となつているが，赤血球 G-6-PD 活性 は減少傾向のみで 3 カ月後も正常値を示すにいたつて いない。

3 ）抗甲状腺剤中断後抗甲状腺剤にて両治療例 (Fig. 4)

Table 1 における Case 5, Case 6 であるが, Case 5 は PBI のみ 4 カ月後正常となつているが, 赤血球 G-6-PD 活性, Triosorb 值ともに6カ月後においても正常值を示していない. Case 6 は Triosorb 值, PBI ともに正常となつているが，赤血球 G-6-PD 活性はむしろやや上昇している. 本症例は治療開始後 2 カ月, 3 カ月, 5 カ月の時点で, それぞれ 2 週間, 6 週間, 2 週間の治燎中断があり, その影響も考えられ る.

4 ）抗甲状腺剤中断後放射性ヨード単独または放射性ヨードと抗甲状腺剂併用例 (Fig. 5)

Table 1 における Case 7, Case 8, Case 9 であるが, Case 7 は Triosorb 值, PBI 赤血球 G-6-PD 活 性ともにほほ平行して正常化している. Case 8 は, Triosorb 值, PBI に比し赤血球 G-6-PD 活性の減少 がおくれている. Case 9 は Triosorb 值, PBI, 赤血球 G-6-PD 活性ともに減少の傾向にあるが, 治療経 過か短くいずれも正常となつていない.

5 ）放射性ヨードで以前に治療したが，不完全治ゆのため抗甲状腺剤にて治療した例 (Fig. 6)

Table 1 そおける Crse 11, Case 12, Gase 13, Case 14 であるが，放射性ヨード治療後抗甲状腺剤の使用 を開始するまでの期間は Table 1 の治療中断期間としてそれぞれの症例について示している. てのさい 4 例とも抗甲状腺剤投与後 2 カ月で Triosorb 值, PBI, 赤血球 G-6-PD 活性のいずれもほぼ同時に正常とな つている. 
Fig. 4. Changes of the erythrocyte G-6-PD activity, Triosorb and PBI in the patients with hyperthyroidism treated by antithyroid drug, who had been treated by antithyroid drug before admission. Case 5 (○), 6 (O) in Table 1. The shaded areas represents normal ranges.

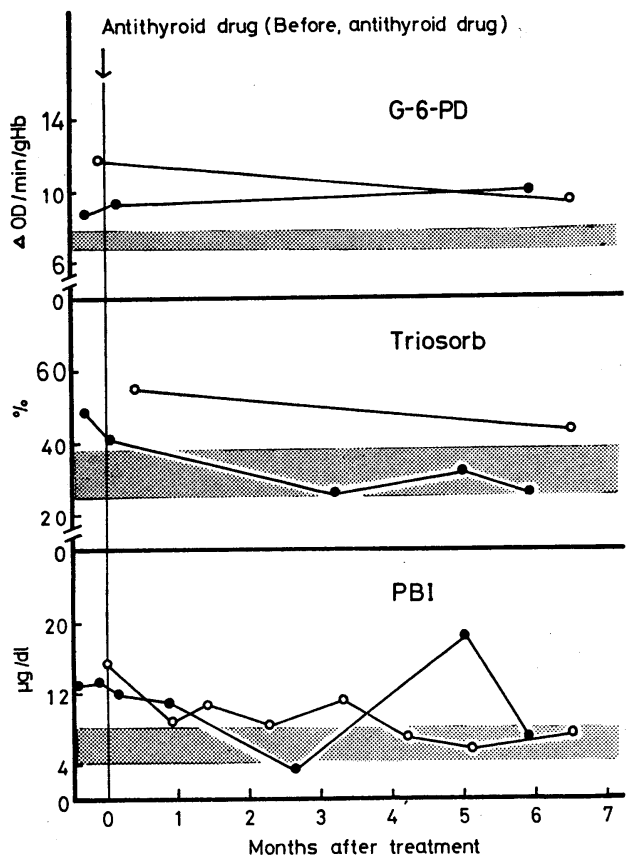

Fig. 5. Changes of the erythrocyte G-6-PD activity, Triosorb and PBI in the patients with hyperthyroidism treated by radioactive iodine and antithyroid drug, who had been treated by antithyroid drug before admission. Case $7(\bigcirc), 8(\bigcirc), 9(\triangle)$ in Table 1 .

The shaded areas represents normal ranges.

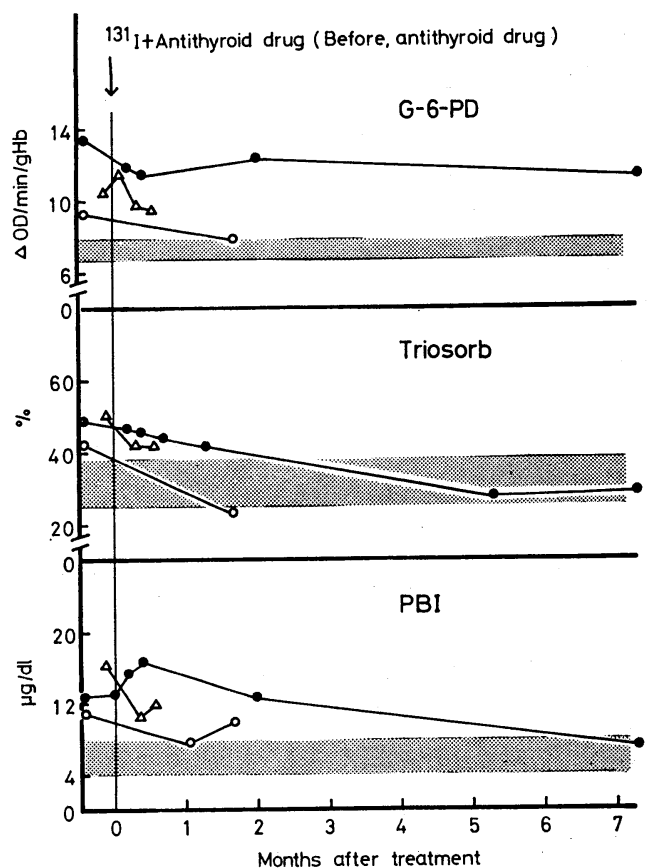

以上をまとめると, 以前に受けた治療の有無とその内容, あらたに開始した治療の内容により, 赤血球 G-6-PD 活性の推移は異つた推移を示すようである. 一般に Triosorb 值や PBI よりおくれて赤血球 G-6$\mathrm{PD}$ 活性が減少していく例が多いが，以前に放射性ヨードによる治療をうけたものでは，抗甲状腺剤にて再 治療した場合，全例において赤血球 G-6-PD 活性が，Triosorb 值，PBI とほぼ同時に正常化するととを示 した.

\section{考 察}

Pearson and Druyan ${ }^{2)}$ は甲状腺機能立進症の 2 例において，治療により赤血球 G-6-PD 活性が正常とな

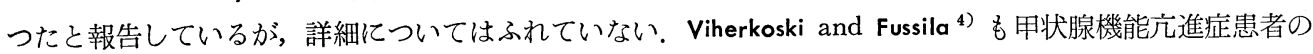
治療により，赤血球 G-6-PD 活性は正常となり，治療開始より赤血球 G-6-PD 活性が正常となるまでの期 間は，重症なものと軽症なものとで異るが，おおむね $2 \sim 4$ カ月であるとのべている. しかし，症例数，治 療法などの詳細については記載がない。また Viherkoski and Lamberg ${ }^{7)}$ は甲状腺機能元進症の治療による 赤血球 G-6-PD 活性の推移についてかなり詳細に観察している。すすおち， carbimazole 単独あるいは carbimazole と放射性ヨードとの併用による治療で，臨床症状とともに甲状腺機能検査成績もよくなり総合 的に euthyroid と判定できると，その時から 1 2 カ月後赤血球 G-6-PD 活性は正常化し，多くの例，特 に重症な甲状腺機能六進症例では，治療開始後 $1 \sim 2$ 力月の期間中に赤血球 G-6-PD 活性は治療前の活性 よりもむしろ上昇する傾向のあることを指摘している。しかしながら，個々の症例についての治療法は明ら 
かでない.

私共は甲状腺機能六進症の治療法別に赤血球 G-6-PD 活性の推移をみたが，治療方法によつて 赤血球 G-6-PD 活性の推移は若干趣を異にする 結果を得た. 大部分の症例では，Triosorb 值, PBI を甲状腺機能の示標としてみた場合，Triosorb 值, PBI が正常化した時点において赤血球 G-6-PD 活性はまだ正常化しておらず，乙の点は Viherkoski and Lamberg ${ }^{7)}$ の結果と一致する点で あつたが，Triosorb 值および PBI が正常化した 時点から赤血球 G-6-PD 活性が正常化するまで の期間は一定していなかつた。一方，以前に放射 性ヨードを服用しており，治ゆ不完全のため抗甲 状腺剤で再治療した 4 例のすべてと，以前に抗甲 状腺剤で治療を受け治療中断後さらに放射性ヨー ドで再治療した 1 例においては, Triosorb 值, PBI の正常化とほぼ同時に赤血球 G-6-PD 活性 も正常化することを示した，以上から放射性ヨ一 ドの使用が，赤血球 G-6-PD 活性の推移に影響 を与えているように思われるが，抗甲状腺剤単独 使用例が少なかつたととと，放射性ヨード使用例 でも赤血球 G-6-PD 活性の正常化が，Triosorb 值，PBI の正常化におくれるものがあつてなお 今後の検討を要する.

Glock and McLean ${ }^{9)}$ は thyroxine をラットに 投与し，肝の G-6-PD 活性が上昇するという.

また，Pearson and Druyan ${ }^{2)}$ は健常人に乾燥甲状腺末，または triiodothyronine を投与し，そのいずれに おいても，数日で赤血球 G-6-PD 活性が上昇し，ホルモンの投与を中止すると急速に赤血球 G-6-PD 活性 が正常化することをみており，甲状腺ホルモンが赤血球 G-6-PD 活性に何らかの機転で影響を与えている という. Pearson and Druyan ${ }^{2)}$ はまた in vitro にて赤血球と triiodothyronine incubate しても赤血球 G-6-PD 活性は上昇しないととを報告しており，てのととと，成熟赤血球には核がなく新らたな酵素の生成 はおこらないことより，甲状腺ホルモンが直接赤血球に作用して G-6-PD 活性を上昇させることは考えが たいとしている. 一方 Viherkoski and Lamberg ${ }^{7)}$ は甲状腺機能六進症の治療により，赤血球 G-6-PD 活性 が, euthyroid になつてから数カ月おくれて正常化するととより, 甲状腺ホルモンの作用点として赤血球生 成の場である骨髄にその原因があろうと推察している。しかし私共の症例において，赤血球 G-6-PD 活性 が甲状腺機能穴進症治療により，Triosorb 值，PBI とほぼ同時に正常化するものもあり，乙のととは全面 的に骨髄説であるとするととに疑問をもたせるものである。赤血球 G-6-PD 活性が，治療により Triosorb 值，PBI とほぼ同時に正常化する例が，いずれも放射性ヨード使用例にかぎられていたてとは，放射性ヨ 一ド自体の赤血球 G-6-PD 活性への影響も考えなくてはならないが，乙れについては今後の検討を行う予 定である。

結 論

1. 14例の甲状腺機能九進症において，治療前後にわたつて赤血球 G-6-PD 活性，Triosorb 值，PBI を 第 49 巻 第 4 号 
測定した. 治療前に高值を示した赤血球 G-6-PD 活性は, 治療により治療後 $3 \sim 4$ 力月頃より 減少の傾向 を認め, 14例中 6 例においては, 赤血球 G-6-PD 活性が正常化した。

2. 甲状腺機能六進症治療により, Triosorb 值, PBI が正常化した時点では, 大部分の症例において, 赤血球 G-6-PD 活性はなお高い傾向があり, その後さらに赤血球 G-6-PD 活性が正常化するまでの期間に ついては一定の傾向がみられなかつた。ただし以前に放射性ヨードの投与がなされ，さらに抗甲状腺剤で再 治療した 4 例では, 全例において, 赤血球 G-6-PD 活性が, Triosorb 值, PBI とほぼ同時に正常化する傾 向を認めた。

（本論文の要旨は第45回日本内分泌学会総会において報告した。）

\section{参 考 文 献}

1) Pitkänen, E. and E.A. Nikkilä : Ann. Med. intern. Fenn., 49 : 197, (1960).

2) Pearson, H.A. and R. Druyan : J.Lab. Clin. Med., $57: 343$, (1961). $\quad 3)$ Tolstrup, N. : Ugeskr. Laeg., $32: 919$, (1966). 4) Viherkoski, M. and R. Fussila : Acta endocr. (Kbh.) Suppl., $119: 207$, (1967). 5) Konttinen, A. and M. Viherkoski : Clin. Chim. Acta, $22: 145$, (1968). 6) 中村恒男, 楠 智 一, 片岡秀久: 日本内分泌学会雑誌, $44: 249$ (1968).

7) Viherkoski, M. and B.-A. Lamberg : Scand. J. Glin. Lab. Invest., 25 : 137, (1970).

8) Kornberg, A. and B.L. Horecker : Methods in Enzymology, Vol. 1 (1955), 323 Academic Press, New York. 9) Glock, G.E. and P. McLean : Biochem. J., 61 : 390, (1955). 